\title{
Diterpenes from Nicotiana glutinosa and their Effect on Fungal Growth
}

\author{
By J. A. BAILEY, G. G. VINCENT AND R. S. BURDEN \\ A.R.C. Plant Growth Substance and Systemic Fungicide Unit, \\ Wye College (University of London), Wye, Ashford, Kent TN25 5 AH
}

(Received 20 May 1974; revised 27 June 1974)

\begin{abstract}
SUMMAR Y
The diterpenes sclareol and I3-epi-sclareol were isolated as a eutectic mixture from leaves of Nicotiana glutinosa. These compounds were probably present in liquid droplets which occurred on the leaf surface. These diterpenes did not prevent germination of fungal spores but markedly inhibited the radial extension of colonies growing on agar. This inhibition is shown to be due to an effect on the morphology of the fungi in which the degree of hyphal branching is increased. The possibility that sclareol/13-epi-sclareol influence the growth-regulatory processes of fungal hyphae and the potential of these compounds to affect growth of fungi on the surface of leaves of $N$. glutinosa is discussed.
\end{abstract}

\section{INTRODUCTION}

Previous research has demonstrated that legumes produce antifungal compounds when they undergo necrosis as a result of virus infection (Bailey \& Ingham, 1971; Klarman \& Hammerschlag, I972; Bailey, 1973; Bailey \& Burden, 1973). The present investigations were started in order to determine whether similar responses occurred in other plant families. In this instance a species of tobacco, Nicotiana glutinosa, was used which develops a necrotic reaction after infection with tobacco mosaic virus. Preliminary experiments, however, demonstrated that extracts of uninoculated leaves possessed antifungal properties. The present paper describes the isolation, identification and effect on fungal growth of compounds isolated from healthy leaves of $N$. glutinosa.

\section{METHODS}

Organisms. Nicotiana glutinosa was grown in sterile compost in a glasshouse with a minimum temperature of $2 \mathrm{I}^{\circ} \mathrm{C}$, or in a plant growth room illuminated by fluorescent lighting at $23 \pm 2{ }^{\circ} \mathrm{C}$.

The isolates of Alternaria brassicicola, Aspergillus niger, Botrytis fabae, Cladosporium cucumerinum, Colletotrichum lagenarium, Colletotrichum lindemuthianum Race $\gamma$, Glomerella cingulata and Septoria nodorum were those used previously (Bailey \& Burden, 1973). Alternaria longipes (IMI 105920) was obtained from the Commonwealth Mycological Institute, Fusarium oxysporum, Rhizoctonia solani and Sclerotinia fructigena were from Dr G. A Carter of this Unit, and Alternaria alternata, Alternaria brassicae, Alternaria solani, Alternaria sp., Phytophthora cinnamomi and Stemphylium botryosum came from the Agricultural Development and Advisory Service, Wye.

Extraction of plant material. Plant tissues were soaked for $48 \mathrm{~h}$ in redistilled benzene. The 
benzene was decanted and the solvent removed by means of a rotary film evaporator at $45{ }^{\circ} \mathrm{C}$. Any water remaining at this stage was removed in a similar way after the addition of a small quantity of ethanol. This procedure resulted in the virtually complete extraction of benzene-soluble material.

Chromatography. This was done on $0.25 \mathrm{~mm}$ silica-gel plates (Merck 5715) using mixtures of hexane and acetone $(3: 1)$ or ethanol and chloroform $(3: 100)$ for development. The resulting chromatograms were examined chemically by spraying with a vanillin reagent (I $\mathrm{g}$ vanillin, $3 \mathrm{ml}$ phosphoric acid and $30 \mathrm{ml}$ methanol) or when assessing extracts for the presence of antifungal compounds by spraying the plates with spores of Cladosporium cucumerinum in Czapek Dox liquid medium. Column chromatography was employed to provide substantial amounts of the inhibitors. Mature leaves $(3.0 \mathrm{~kg})$ were kept at $-20{ }^{\circ} \mathrm{C}$ for several days and extracted with benzene (4 1 ) for 3 days at room temperature. The benzene was removed and the residue re-extracted with further benzene $(31)$. The combined extracts were evaporated, redissolved in benzene $(5 \mathrm{ml})$ and chromatographed on a column of silicic acid $(200 \mathrm{~g})$. The column was eluted with hexane $(200 \mathrm{ml}), 5 \%$ acetone in hexane $(600 \mathrm{ml}), 7 \%$ acetone in hexane $(600 \mathrm{ml})$ and finally with $10 \%$ acetone in hexane (I 1$)$. Fractions of $25 \mathrm{ml}$ were collected and each fraction was examined by thin-layer chromatography using the vanillin reagent.

Extracts, which had been evaporated and redissolved in ethyl acetate, were also examined by means of a Pye I04 gas-liquid chromatogram fitted with a column containing $3 \%$ OV-225 and operated at $215{ }^{\circ} \mathrm{C}$. The concentrations of compounds in extracts were assessed by comparing the peak areas obtained from the extract with those obtained from standard solutions prepared from compounds which had been purified by recrystallization from hexane.

Assays of antifungal activity. Activity was assessed by measuring the germination of fungal spores on glass slides and on agar, and the growth of hyphae both in liquid medium and on agar. The methods used have been reported previously (Bailey \& Deverall, I97I ; Bailey \& Burden, 1973); any amendments are described in the text.

\section{RESULTS}

Demonstration and isolation of inhibitors of fungal growth from leaves of Nicotiana glutinosa

Mature leaves, removed from ten-week-old plants which had been grown in a glasshouse, were extracted with benzene. The benzene was removed and the ether-soluble residue was subjected to thin-layer chromatography in hexane and acetone $(3: \mathrm{I})$. The resulting chromatogram was assayed for antifungal activity by using Cladosporium cucumerinum. A large area of inhibition was demonstrated at $R_{F} 0.17$ and other minor areas of inhibition were visible at $R_{F} 0.27,0.23,0.13$ and 0.11 . When similar chromatograms were sprayed with vanillin reagent and heated, several regions of the chromatogram, at $R_{F} 0.47,0.17,0.14$ and $0.1 \mathrm{I}$, became coloured dark blue. The major inhibitory area at $R_{F} 0.17$ was investigated more closely by repeating the chromatography and eluting the silica with ethyl acetate. Removal of the solvent yielded a gum which crystallized in hexane giving a compound which had a melting point of 96 to $100{ }^{\circ} \mathrm{C}$.

\section{Identification of inhibitor as sclareol/13-epi-sclareol}

Two grams of the compound of m.p. 94 to $99{ }^{\circ} \mathrm{C}$ were obtained by column chromatography (fractions 35 to 54 ). Repeated crystallization from hexane did not raise the melting point. However, by using methanol, colourless needles, m.p. 127 to $128^{\circ} \mathrm{C}$, were obtained 


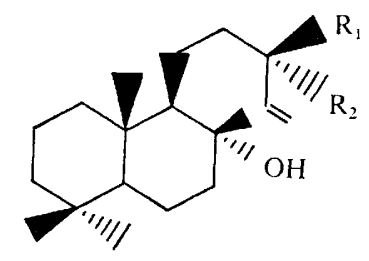

Fig. I. Structures of sclareol and 13-epi sclareol. Sclareol: $R_{1}=O H, R_{2}=$ Me. I3-Epi sclareol: $\mathrm{R}_{1}=\mathrm{Me}, \mathrm{R}_{2}=\mathrm{OH}$.

after considerable loss of material. The compound analysed well for $\mathrm{C}_{20} \mathrm{H}_{36} \mathrm{O}_{2}$ (values found were $77.98 \% \mathrm{C}$, I I.60 \% $\mathrm{H} ; \mathrm{C}_{20} \mathrm{H}_{36} \mathrm{O}_{2}$ requires $77 \cdot 85 \% \mathrm{C}$ and I I $77 \% \mathrm{H}$ ), but the highest peak observed in the mass spectrum was at $\mathrm{m} / \mathrm{e} 290$. This peak could result from a loss of a molecule of water from the molecular ion. In the nuclear magnetic resonance spectrum resonances were observed from 5 methyl groups $(\delta 0 \cdot 76,6 \mathrm{H}, \mathrm{s} ; \delta 0 \cdot 86,3 \mathrm{H}, \mathrm{s} ; \delta \mathrm{I} \cdot \mathrm{I} 2,3 \mathrm{H}$, $\mathrm{s} ; \delta \mathrm{I} \cdot 23,3 \mathrm{H}, \mathrm{s})$, two hydroxyl groups $\left(\delta 2 \cdot 70,2 \mathrm{H}\right.$, s, which disappeared in $\left.\mathrm{D}_{2} \mathrm{O}\right)$ and a vinyl group which appeared as a characteristic I2-line $\mathrm{ABX}$ spectrum $\left(\delta \mathrm{H}_{\mathrm{A}} 5 \cdot 07, \delta \mathrm{H}_{\mathrm{B}} 5 \cdot 23\right.$, $\delta \mathrm{H}_{\mathrm{X}} 5^{\cdot 92}, \mathrm{~J}_{\mathrm{AB}}=2, \mathrm{~J}_{\mathrm{AX}}=\mathrm{I} \mathrm{O}, \mathrm{J}_{\mathrm{BX}}=8$ ). Both hydroxyl groups appeared to be tertiary as the compound did not give an acetate on treatment with acetic anhydride and pyridine.

The nature of the substance is indicated from work by Popa \& Lazurevskii (1963), who obtained a diterpene sclareol together with its 13-epimer from the buds of Salvia sclarea. They found that the mixture of sclareol//3-epi-sclareol formed a eutectic in hexane, m.p. $95^{\circ} \mathrm{C}$, but that the $\mathrm{I} 3$-epimer could be separated by recrystallization from methanol to yield a crystalline solid, m.p. 129 to $130{ }^{\circ} \mathrm{C}$.

Our data agree well with these findings and the analytical and spectral data of the compound of m.p. I 27 to $\mathrm{I} 28^{\circ} \mathrm{C}$ are in complete accordance with its formulation as I3-episclareol. The original substance, m.p. 94 to $99{ }^{\circ} \mathrm{C}$, is therefore formulated as a mixture of sclareol and I3-epi-sclareol (Fig. I) and this mixture was used in all subsequent experiments. Throughout the rest of this paper the mixture sclareol/13-epi-sclareol is referred to as 'sclareol'.

\section{Concentration and distribution of 'sclareol' in tissues of Nicotiana glutinosa}

During the isolation of the sclareol mixture, experiments had shown some variation in the amounts of diterpenes isolated from the tobacco leaves. The distribution of 'sclareol' within the plant and the effect of leaf age on its concentration was measured by gasliquid chromatography. Typical chromatographic traces obtained from an extract of mature leaves and from a crystalline sample of 'sclareol' are shown in Fig. 2. This illustrates that 'sclareol' behaved as a single compound which was readily separated from other components in the extract. The concentrations of 'sclareol' in individual leaves, flower spike, stem and roots were measured. The results (Table I) demonstrate that only trace amounts of these compounds were present in root tissues but there were large quantities in all the aerial parts of the plant. Although these results showed that highest concentrations were obtained from the upper, younger, parts of the plant, where levels exceeded $600 \mu \mathrm{g} / \mathrm{g}$ tissue, other experiments indicated that the level of 'sclareol' in all tissues increased as they matured.

The location of 'sclareol' within leaf tissues was also investigated. A single leaf was shaken successively in four Io $\mathrm{ml}$ portions of ethyl acetate for $60 \mathrm{~s}$. The leaf was then extracted in Io $\mathrm{ml}$ benzene for $\mathrm{I} 8 \mathrm{~h}$. The ethyl acetate and benzene extracts were evaporated and the residue was redissolved in $\mathrm{I} \mathrm{ml}$ ethyl acetate. The concentration of 'sclareol' was measured 

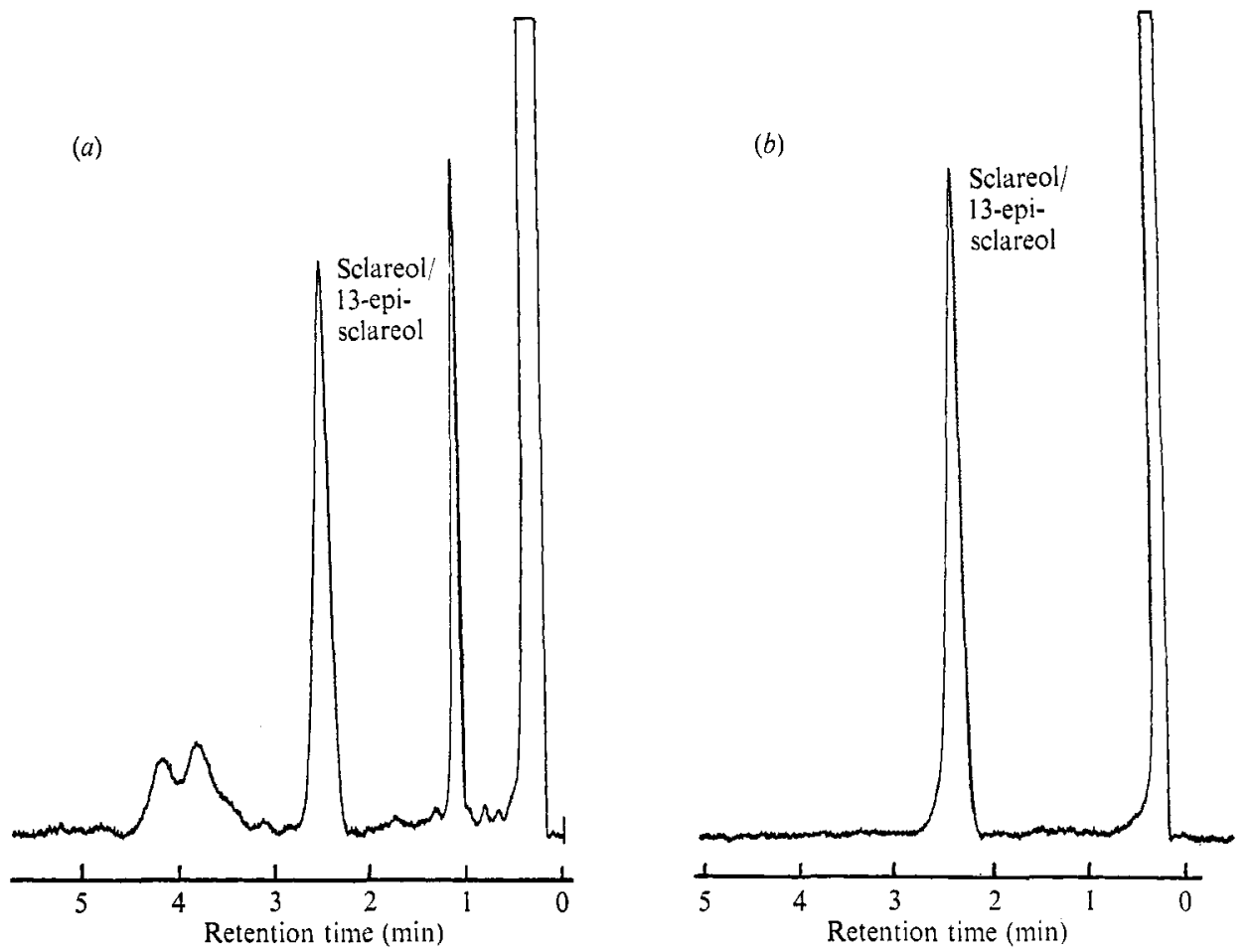

Fig. 2. Gas-liquid chromatographic analysis of 'sclareol'. (a) Two $\mu 1$ of an extract of Nicotiana glutinosa leaves ( $\mathrm{I} \mathrm{g}$ ) in ethyl acetate ( $\mathrm{I} \mathrm{ml).} \mathrm{(b)} \mathrm{Two} \mu \mathrm{l}$ of a solution of 'sclareol' in ethyl acetate $(600 \mu \mathrm{g} / \mathrm{ml})$.

Table I. Concentration of 'sclareol' in tissues of Nicotiana glutinosa

\begin{tabular}{|c|c|c|c|}
\hline Tissue* & $\begin{array}{l}\text { Concentration } \\
(\mu \mathrm{g} / \mathrm{g} \text { tissue })\end{array}$ & Tissue* & $\begin{array}{c}\text { Concentration } \\
(\mu \mathrm{g} / \mathrm{g} \text { tissue })\end{array}$ \\
\hline Roots & I & Leaf 10 & 195 \\
\hline Leaf I & 19 & Leaf I I & 264 \\
\hline Leaf 2 & 20 & Leaf I 2 & 274 \\
\hline Leaf 3 & 52 & Leaf 13 & 391 \\
\hline Leaf 4 & 43 & Leaf 14 & 366 \\
\hline Leaf 5 & 90 & Leaf 15 & 619 \\
\hline Leaf 6 & 100 & Leaf I 6 & 606 \\
\hline Leaf 7 & 162 & Leaf 17 & 537 \\
\hline Leaf $8^{\circ}$ & 359 & Flowerbuds & 632 \\
\hline Leaf 9 & 319 & Stem & 408 \\
\hline
\end{tabular}

* Leaf I was the oldest leaf, leaf I 7 the youngest. Leaves I, 2, 3 and 4 were in part chlorotic, leaves 5 to 14 were dark green and fully expanded, and leaves 15 to 17 were also dark green but were not fully expanded.

by gas-liquid chromatography. The results (Table 2) demonstrate that most 'sclareol' was present in the first ethyl acetate solution, very little being detected in the subsequent ethyl acetate extracts or in the benzene extract of leaf tissues. When leaves were examined with a binocular microscope they were found to be covered with numerous hairs bearing droplets of liquid. These droplets dispersed when ethyl acetate was placed on the surface of the leaf. In other experiments, a weighed glass slide was pressed on to a leaf without bruising it and 

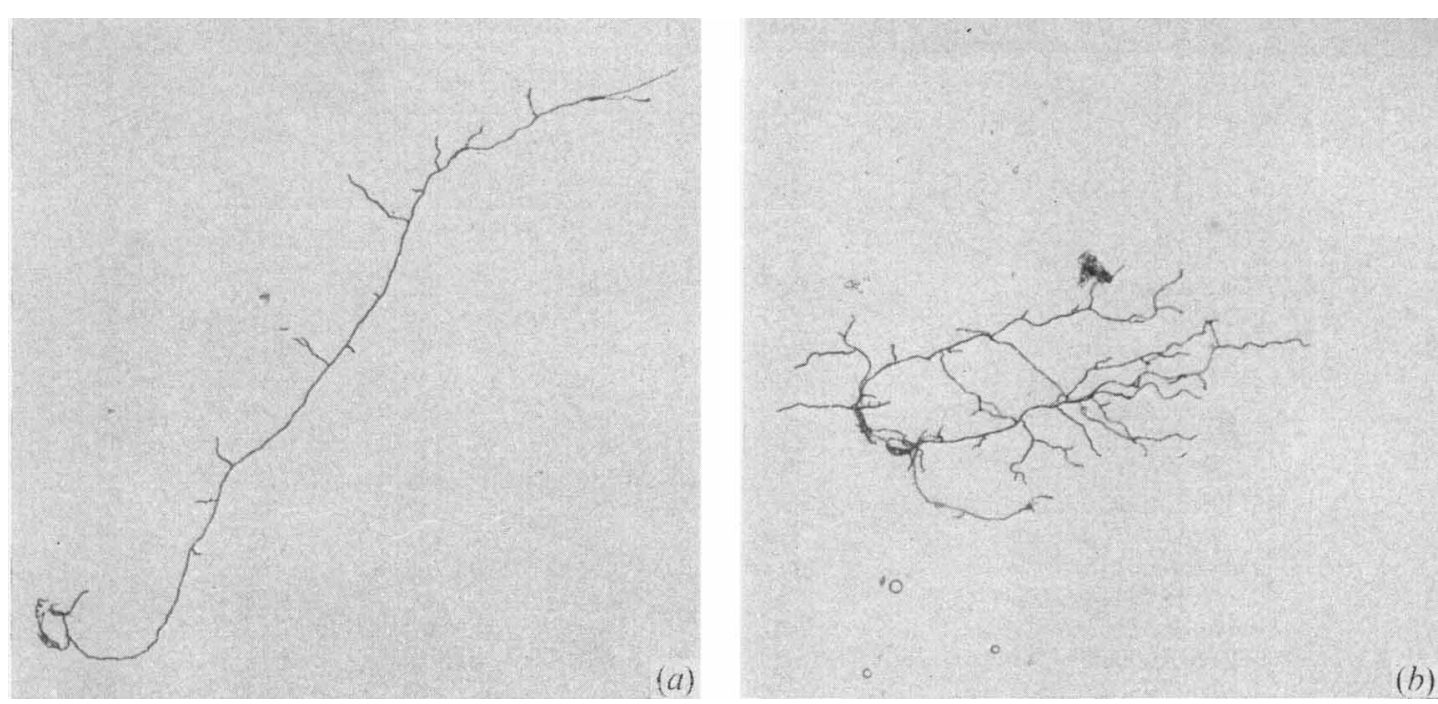

Fig. 3. Effect of 'sclareol' on germ-tube growth of Alternaria longipes. Spores were distributed on to agar and the plates incubated for $24 \mathrm{~h}$. (a) Czapek Dox agar. (b) Czapek Dox agar incorporating $20 \mu \mathrm{g}$ 'sclareol' $/ \mathrm{ml}$. Both agars contained $0.5 \%(\mathrm{w} / \mathrm{v})$ dimethylsulphoxide.

\title{
Table 2. Distribution of 'sclareol' in leaf tissues of Nicotiana glutinosa
}

\begin{abstract}
A leaf $(0.5 \mathrm{~g})$ was placed in four successive $10 \mathrm{ml}$ portions of ethyl acetate for $60 \mathrm{~s}$ (extracts $\mathrm{I}$ to 4 respectively) and in $\mathrm{I} O \mathrm{ml}$ benzene for $\mathrm{I} 8 \mathrm{~h}$ (extract 5 ). The weight of 'sclareol' in these extracts was measured by gas-liquid chromatography.
\end{abstract}

$\begin{array}{cc}\text { Extract } & \begin{array}{c}\text { Weight of 'sclareol' } \\ (\mu \mathrm{g})\end{array} \\ \text { I } & 621 \cdot 0 \\ 2 & 13 \cdot 8 \\ 3 & 1 \cdot 4 \\ 4 & 1 \cdot 4 \\ 5 & 2 \cdot 8\end{array}$

then removed. The amount of liquid transferred to the glass surface was obtained by reweighing, and the fluid was then dissolved in ethyl acetate. Analysis of the fluid by gasliquid chromatography showed that the leaf droplets contained about $10 \%(\mathrm{w} / \mathrm{w})$ of sclareol.

\section{Antifungal activity of sclareol/13-epi-sclareol}

Activity on silica gel. Quantities of crystalline 'sclareol' were dissolved in ether and applied to silica gel layers, as $\mathrm{I} \mathrm{cm}$ origins. The plates were developed in hexane and acetone $(3: \mathrm{I})$ and assayed for antifungal activity against Cladosporium cucumerinum. The smallest amount which caused inhibition of growth was $100 \mu \mathrm{g}$.

Activity against germination of fungal spores. By means of the microscope slide assay, it was found that 'sclareol' at concentrations up to $500 \mu \mathrm{g} / \mathrm{ml}$ did not prevent the germination in Czapek Dox liquid medium of spores of Alternaria brassicicola, Alternaria longipes, Aspergillus niger, Botrytis cinerea, Cladosporium cucumerinum or Colletotrichum lindemuthianum. Repetitions of these tests at $\mathrm{pH} 4.0, \mathrm{pH} 6.8$ or in media supplemented with $15 \%$ $(\mathrm{w} / \mathrm{v})$ ethanol or $0.5 \%(\mathrm{w} / \mathrm{v})$ dimethylsulphoxide also revealed no inhibition of spore germination. 
Table 3. The effect of 'sclareol' on the linear mycelial growth rate of several fungi

\begin{tabular}{|c|c|c|c|c|}
\hline & \multicolumn{4}{|c|}{ Linear growth rate* $(\%)$} \\
\hline & \multicolumn{4}{|c|}{$\begin{array}{c}\text { Concn of } \\
\text { 'sclareol' }(\mu \mathrm{g} / \mathrm{ml})\end{array}$} \\
\hline & o† & 5 & 20 & 100 \\
\hline Alternaria longipes & 142 & $88 \div$ & $34+$ & $20 \ddagger$ \\
\hline Sclerotinia fructigena & 150 & $94 \%$ & $38+$ & $24 t$ \\
\hline A. brassicicola & 105 & $83 \div$ & $39 \ddagger$ & $45 \ddagger$ \\
\hline Rhizoctonia solani & 106 & $89 \div$ & $43 \ddagger$ & $38 \ddagger$ \\
\hline Cladosporium cucumerinum & 83 & $58 \ddagger$ & $51 \div$ & $40 \%$ \\
\hline Botrytis fabae & 117 & $90 \ddagger$ & $47 \%$ & $4 \mathrm{I}+$ \\
\hline A. alternata & I I 2 & II 5 & $84 \div$ & $4 I \ddagger$ \\
\hline Colletotrichum lindemuthianum & 107 & $67 \div$ & $56 \ddagger$ & $43 \div$ \\
\hline Aspergillus niger & 116 & $87 \ddagger$ & $58 t$ & $47+$ \\
\hline Fusarium oxysporum & II 5 & $97+$ & $59+$ & $48 \div$ \\
\hline Glomerella cingulata & $9 I$ & $94 \div$ & $60_{+}^{\circ}$ & 51 \\
\hline Stemphylium botryosum & 143 & 120 & $70 \div$ & $55 \%$ \\
\hline Alternaria sp. & 87 & $87 t$ & $68 \ddagger$ & $63 \ddagger$ \\
\hline Colletotrichum lagenarium & 105 & $83 \div$ & $71 \%$ & 63 \\
\hline A. brassicae & 122 & IOI & $87 \div$ & $66 \$$ \\
\hline A. solani & 100 & IOI & 95 & $74 t$ \\
\hline Septoria nodorum & 104 & 98 & I03 & 95 \\
\hline Phytophthora cinnamomi & 125 & II9 & I 18 & IOI \\
\hline
\end{tabular}

* Growth rates are expressed as a percentage of the rate on Czapek Dox agar containing $0.5 \%$ dimethylsulphoxide. Mean of three replicates.

$\dagger$ Growth rate on agar lacking dimethylsulphoxide.

$\ddagger$ Growth rate significantly less $(P=5 \%)$ than on agar lacking 'sclareol'.

Table 4. Effect of 'sclareol' on mycelial growth of Cladosporium cucumerinum and Alternaria longipes in liquid medium

Assays were carried out in $100 \mathrm{ml}$ Czapek Dox liquid medium containing $0.5 \%$ dimethylsulphoxide. The weights of mycelium were measured after Io days. Values presented are the means of two replicates.

$$
\begin{gathered}
\text { Concn of 'sclareol' } \\
(\mu \mathrm{g} / \mathrm{ml})
\end{gathered}
$$$$
\begin{array}{r}
0 \\
10 \\
25 \\
100 \\
500
\end{array}
$$

Weight of mycelium (mg \pm s.E.M.)

$\begin{array}{cc}\text { Alternaria longipes } & \text { Cladosporium cucumerinum } \\ 75 \cdot 2 \pm 0.05 & 163 \\ 86.5 \pm 14 \cdot 2 & 184 \pm 9 \cdot 9 \\ 79 \cdot 3 \pm 7 \cdot 7 & 165 \pm 7 \cdot 2 \\ 84 \cdot 3 \pm 21 \cdot 8 & 165 \pm 0.5 \\ 82.5 \pm 9.9 & 139 \pm 6.9\end{array}$

Further experiments were carried out in which spores were placed on agar containing $0.5 \%(\mathrm{w} / \mathrm{v})$ dimethylsulphoxide and incorporating 'sclareol'. As above, the germination of spores of Cladosporium cucumerinum, Alternaria brassicicola and A. longipes was not affected. However, when germinated spores of both species of Alternaria were incubated further, it was observed that the colonies produced on agar incorporating 'sclareol' (> 10 $\mu \mathrm{g} / \mathrm{ml})$ expanded slowly and the agar surface became covered with discrete colonies ( $\mathrm{I}$ to $3 \mathrm{~mm}$ diam). In the absence of 'sclareol' colonies expanded rapidly and covered the entire agar surface. This effect was examined with a microscope and is illustrated in Fig. 3. On agar alone, both $A$. brassicicola and $A$. longipes produced hyphal growth which was predominately at the apex, with very little extension of the lateral branches. Apical growth was reduced in the presence of 'sclareol' but branch development was greatly enhanced. 
Activity against growth of fungal mycelium. The effect of 'sclareol' on the growth of mycelium on Czapek Dox agar was also assessed. The results (Table 3) demonstrate that the radial growth rates of I6 species of fungi were significantly reduced by $20 \mu \mathrm{g}$ 'sclareol' $/ \mathrm{ml}$ agar. Phytophthora cinnamomi and Septoria nodorum were unaffected. The effect of 'sclareol' on the mycelial growth of Cladosporium cucumerinum and Alternaria longipes in Czapek Dox liquid is shown in Table 4. These results show that no major reduction in the weight of mycelia was produced after incubation for Io days.

\section{DISCUSSION}

Extracts of $N$. glutinosa produced several areas of fungal growth inhibition on silica gel plates when assayed by means of Cladosporium cucumerinum. The material responsible for the major inhibitory area was identified as a mixture of sclareol and 13-epi-sclareol. Although this mixture inhibited $C$. cucumerinum on silica plates it did not prevent spore germination on glass slides or reduce the amount of mycelia produced in liquid media. However, as discussed below, it did inhibit the radial growth of mycelial colonies on agar. These results indicate that fungitoxicity on silica plates should be interpreted with caution and be investigated further in other in vitro assays.

'Sclareol' was isolated from the flower buds of Salvia sclarea but no fungitoxic activity was reported (Popa \& Lazurevskii, 1963). Results obtained with $N$. glutinosa show that these compounds can be extracted from all aerial parts of the plant. Subsequent experiments indicate that 'sclareol' is located at high concentrations in the liquid droplets which occur on the leaf surface.

The observations that, on agar, low concentrations of these diterpenes reduce the hyphal extension of a wide range of fungal species is of interest since the loss of apical dominance resembles a hormonal effect. The lateral branches, which were present but short in normal hyphae, had extended considerably on agar containing 'sclareol'. This increased branching and loss of apical growth explains the inhibition of hyphal extension across agar surfaces. Similar morphological effects have been reported for other compounds. For instance, at high concentrations (50 to $100 \mathrm{mg} / \mathrm{ml}$ ), L-sorbose caused Neurospora crassa to branch profusely (Trinci \& Collinge, 1973), and the antibiotics cytochalasin A and $\mathrm{B}$ ( 12.5 to $100 \mu \mathrm{g} / \mathrm{ml})$ caused branching at the edges of developing colonies of Botrytis cinerea (Betina, Mičeková \& Nemec, 1972). However, the action of griseofulvin is most comparable with the effects reported here since this compound, at a concentration of $0.1 \mu \mathrm{g} / \mathrm{ml}$, has been shown to cause excessive branching and curling of hyphae of Botrytis allii. In the presence of higher concentrations (Io $\mu \mathrm{g} / \mathrm{ml}$ ) hyphae failed to develop. Subsequently, griseofulvin was found to affect many fungi but it had no effect on Oomycetes (Brian, I949). In the present paper 'sclareol' inhibited a wide range of fungi, and investigations with Alternaria brassicicola and $A$. longipes revealed that this arose from a greater degree of branching. Thus, these results suggest that 'sclareol', like griseofulvin, affects the growth-regulatory systems of fungi.

Finally it is necessary to emphasize that 'sclareol' was present on the surface of leaves of $N$. glutinosa at concentrations which are capable of influencing the growth of many species of fungi. These could include the saprophytic flora and also species pathogenic to $N$. glutinosa. It has not been possible to infect leaves of $N$. glutinosa, $N$. clevelandii or $N$. tabacum cultivar White Burley with the isolate of $A$. longipes used in this work and therefore no conclusions can be drawn regarding a role for these compounds in vivo. However, studies on the significance of sclareol and of glutinosone, an antifungal sesquiterpene isolated from 
virus-infected N. glutinosa (Burden, Bailey \& Vincent, 1974), in resistance to attack by fungi are continuing in this laboratory.

We thank Professor R. L. Wain for his continuing encouragement and advice. We are grateful to the Agricultural Development and Advisory Service, Wye for supplying various fungal cultures.

\section{REFERENCES}

Bailey, J. A. (1973). Production of antifungal compounds in cowpea (Vigna sinensis) and pea (Pisum sativum) after virus infection. Journal of General Microbiology 75, I19-123.

Bailey, J. A. \& Burden, R. S. (I973). Biochemical changes and phytoalexin accumulation in Phaseolus vulgaris following cellular browning caused by tobacco necrosis virus. Physiological Plant Pathology 3, I7I-I 77 .

Bailey, J. A. \& Deverall, B. J. (I971). Formation and activity of phaseollin in the interaction between bean hypocotyls (Phaseolus vulgaris) and physiological races of Colletotrichum lindemuthianum. Physiological Plant Pathology I, 435-449.

Bailey, J. A. \& INGHAM, J. L. (1971). Phaseollin accumulation in bean (Phaseolus vulgaris) in response to infection by tobacco necrosis virus and the rust Uromyces appendiculatus. Physiological Plant Pathology r, 45I-456.

Betina, V., MičekovÁ, D. \& Nemec, P. (1972). Antimicrobial properties of cytochalasins and their alteration of fungal morphology. Journal of General Microbiology 7r, 343-349.

Burden, R. S., Bailey, J. A. \& Vincent, G. G. (1974). The structure of glutinosone, a new antifungal sesquiterpene from Nicotiana glutinosa infected with tobacco mosaic virus. Phytochemistry (in the Press).

BRIAN, P. W. (1949). Studies on the biological activity of griseofulvin. Annals of Botany 13, 59-77.

Klarman, W. L. \& Hammerschlag, F. (1972). Production of the phytoalexin, hydroxyphaseollin, in soybean leaves inoculated with tobacco necrosis virus. Phytopathology 62, 719-721.

PoPA, D. P. \& LAZUREVSKII, G. V. (I963). Synthesis based on sclareol. VII. Sclareol and 13-epi-sclareol from Salvia sclarea. Zhurnal obshchei khimii 33, 303-307.

TRINCI, A. P. J. \& Collinge, A. (I973). Influence of L-sorbose on the growth and morphology of Neurospora crassa. Journal of General Microbiology 78, 179-192. 